\title{
Melanoma extracted from the common bile duct
}

\author{
Mark R Borgaonkar MD MSc FRCPC
}

54-year old woman presented to hospital with two days of epigasAtric pain, nausea and vomiting. Her history was significant for malignant melanoma of the right leg, diagnosed five years earlier, with subsequent endometrial, breast, lung and cerebral metastases. Liver enzyme levels were elevated (aspartate aminotransferase $230 \mathrm{IU} / \mathrm{L}$, alanine aminotransferase $336 \mathrm{IU} / \mathrm{L}$ ), with a total bilirubin level of $178 \mu \mathrm{mol} / \mathrm{L}$. Computed tomography scanning demonstrated biliary dilation and a distal common bile duct (CBD) mass.

\section{DIAGNOSIS}

Endoscopic retrograde cholangiopancreatography demonstrated an oblong, distal filling defect (Figure 1). Following sphincterotomy and balloon sweep, a soft tissue mass was extracted (Figure 2). This was retrieved with a basket and sent for histological analysis that demonstrated malignant cells consistent with melanoma (Figure 3). The patient's obstructive jaundice resolved but she unfortunately succumbed to her illness three weeks later.

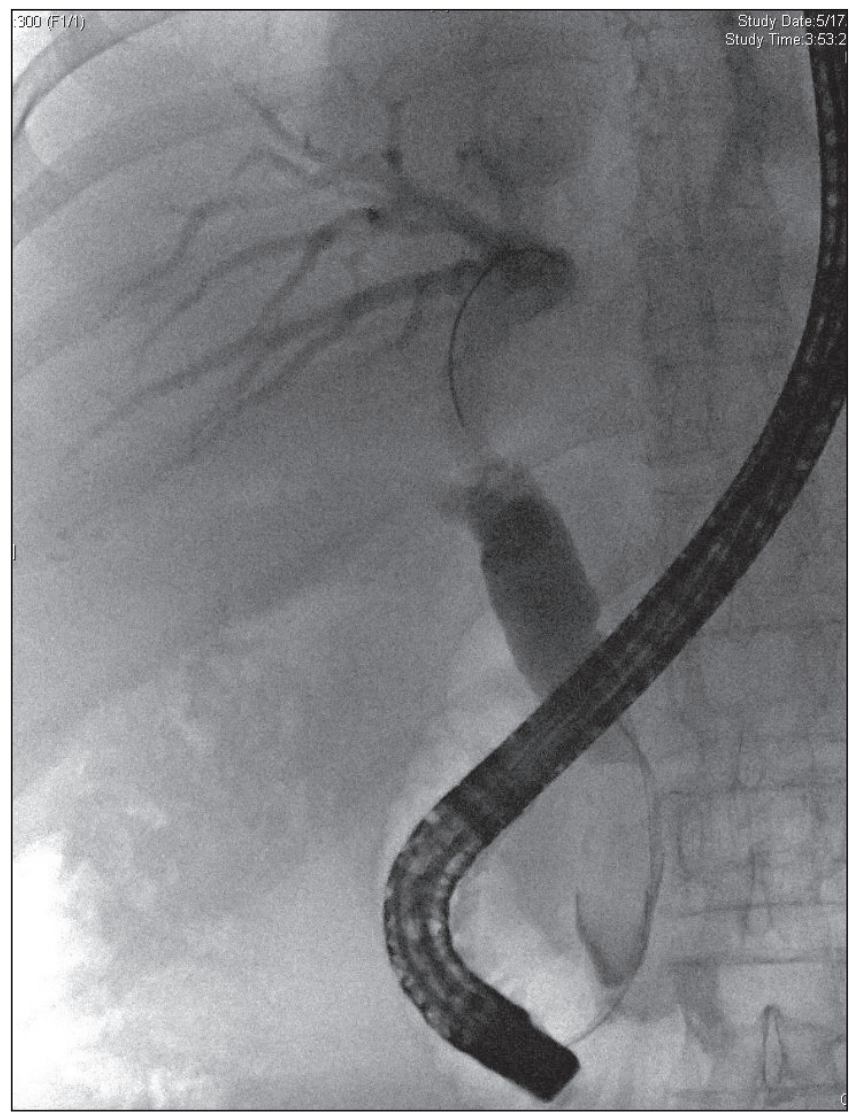

Figure 1) Cholangiogram demonstrating distal filling defect causing biliary obstruction

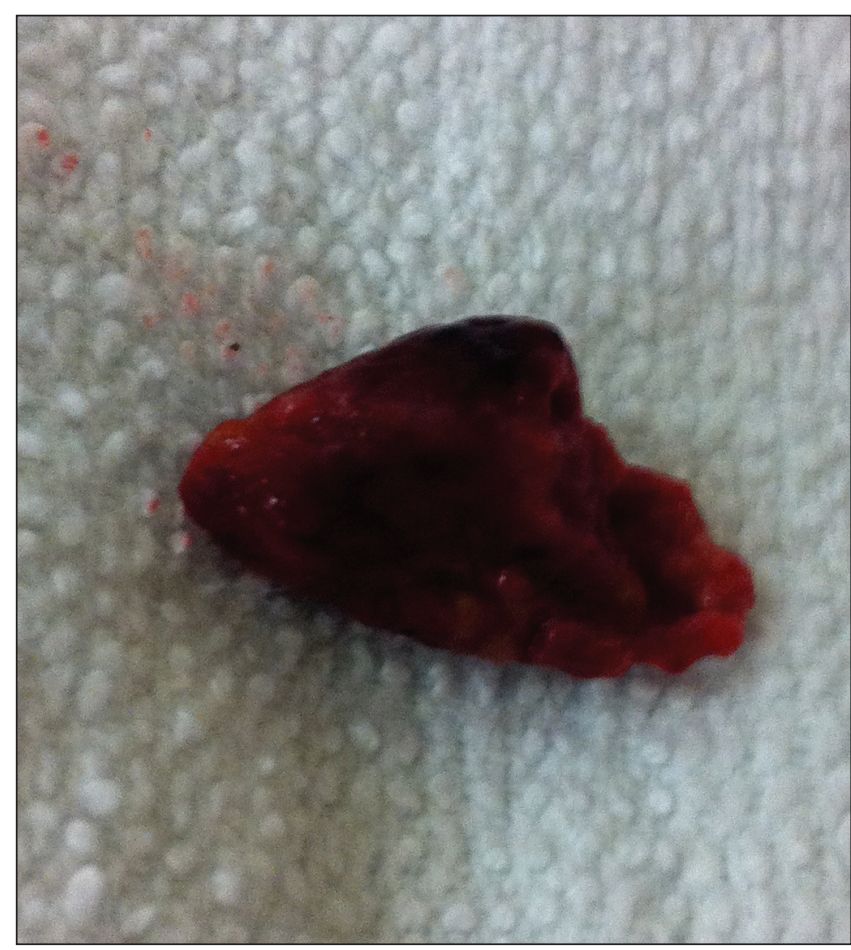

Figure 2) Gross specimen of mass extracted from the common bile duct

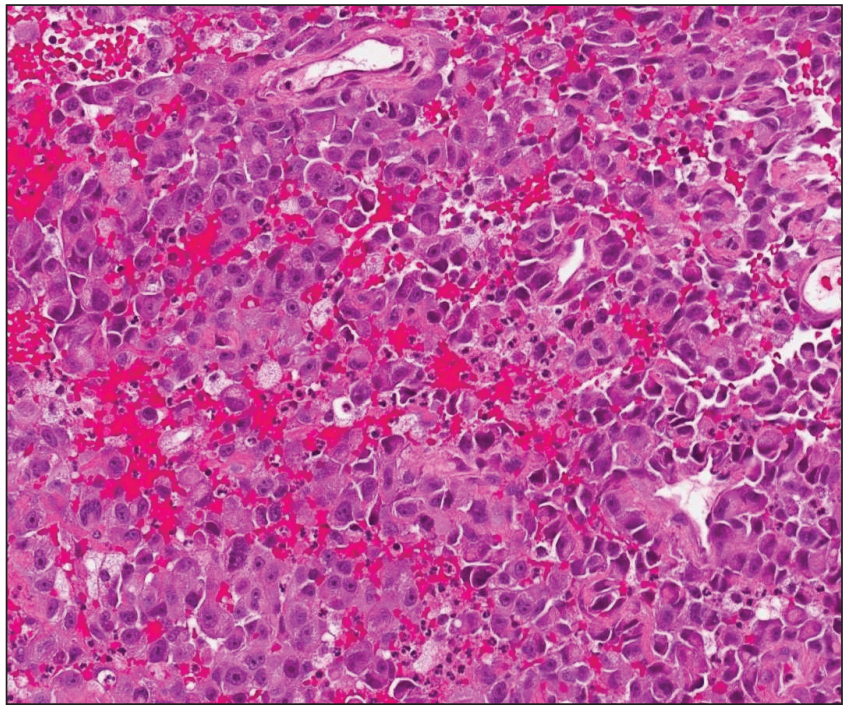

Figure 3) Histology of mass demonstrating malignant cells consistent with metastatic melanoma. Hematoxylin and eosin stain, original magnification $\times 20$

Memorial University of Newfoundland, St John's, Newfoundland and Labrador

Correspondence: Dr Mark R Borgaonkar, Department of Medicine, Memorial University of Newfoundland, 300 Prince Phillip Drive,

St John's Newfoundland and Labrador A1B 3V6. Telephone 709-777-8072, fax 709-777-7054, e-mail markb@mun.ca

Received for publication December 21, 2011. Accepted December 30, 2011 


\section{DISCUSSION}

Cases of primary melanoma of the ampulla and CBD have been reported (1), as have cases of metastases to the biliary tree $(2,3)$. The present case is just the second report of metastatic melanoma extracted from the CBD and serves as another example of the unusual behaviour of this particular malignancy (4).

\section{REFERENCES}

1. Agrawal D, Tannous GC, Chak A. Primary malignant melanoma of the hepatic duct: A case report. Gastrointest Endosc 2010;72:845-6.
2. van Bokhoven MM, Aarntzen EH, Tan AC. Metastatic melanoma of the common bile duct and ampulla of Vater. Gastrointest Endosc 2006;63:873-4.

3. Uchikov A, Genova S, Dimitrov I, Entchev A, Dimov R, Stefanov C. A case of melanoma metastatic to the gallbladder and the common bile duct with clinical presentation of obstructive jaundice and bilirubinemia. J BUON 2004;9:317-9.

4. Thompson JF, Mathur MN, Coates AS. Common bile duct obstruction due to intraluminal metastatic melanoma. Aust N Z J Surg 1993;63:502-4.

The Canadian Journal of Gastroenterology is now considering a limited number of submissions for IMAGE OF THE MONTH. These are be based on endoscopic, histological, radiological and/or patient images, which must be anonymous with no identifying features visible. The patient must consent to publication and the consent must be submitted with the manuscript. All manuscripts should be practical and relevant to clinical practice, and not simply a case report of an esoteric condition. The text should be brief, structured as CASE PRESENTATION and DISCUSSION, and not more than 700 words in length. A maximum of three images can be submitted and the number of references should not exceed five. The submission may be edited by our editorial team.

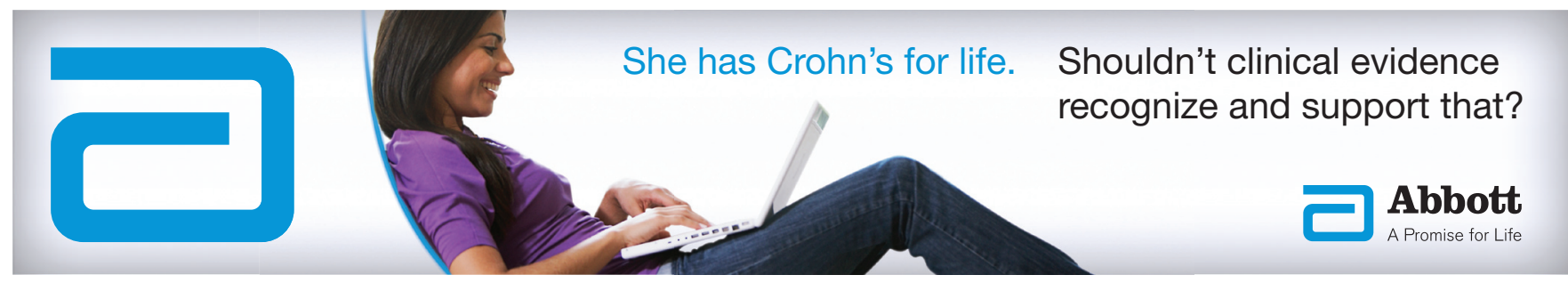




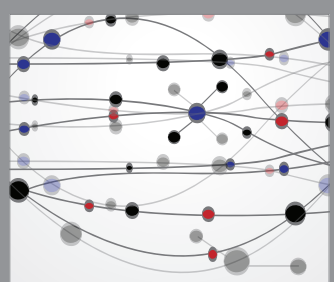

The Scientific World Journal
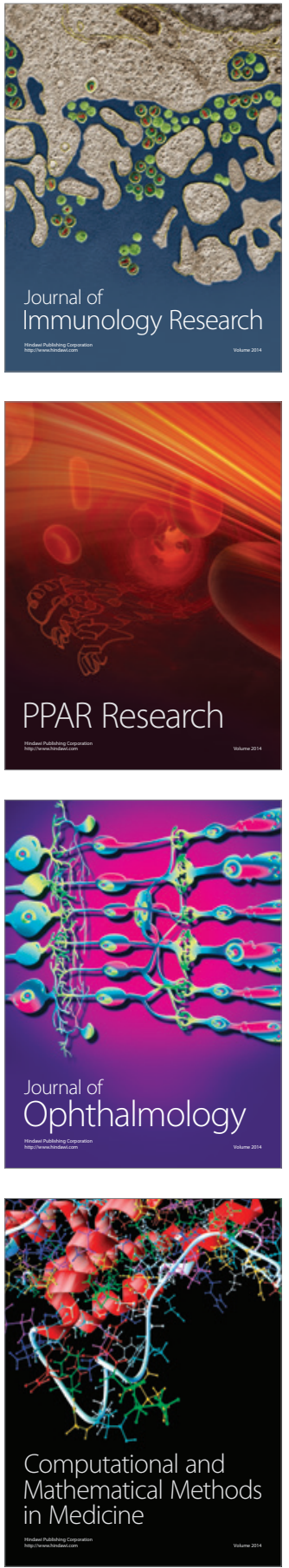

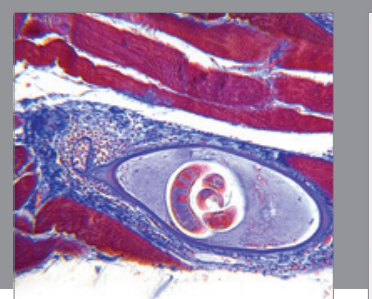

Gastroenterology Research and Practice

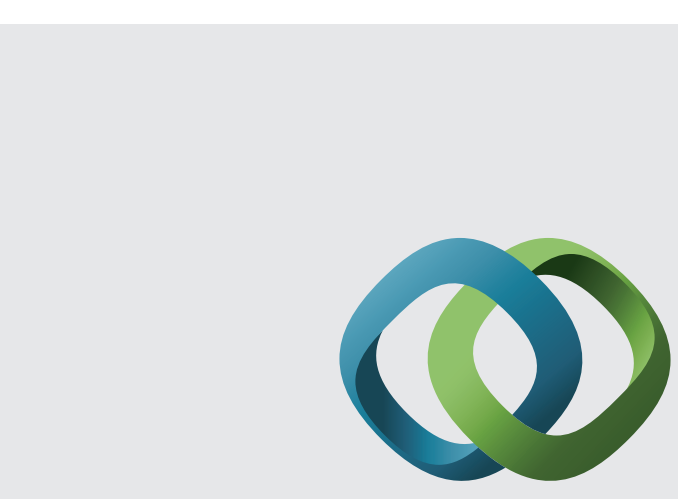

\section{Hindawi}

Submit your manuscripts at

http://www.hindawi.com
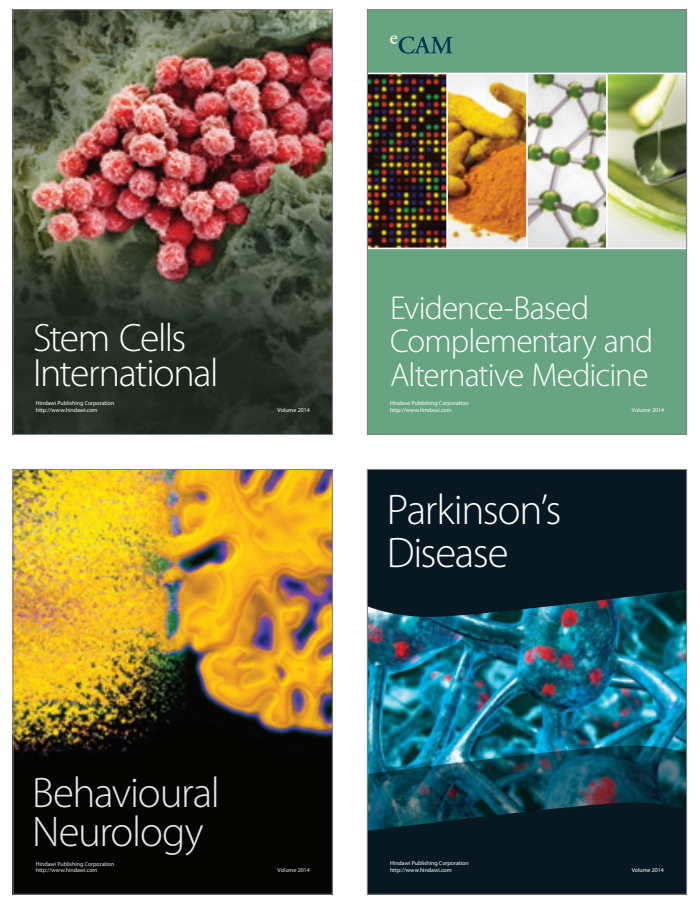
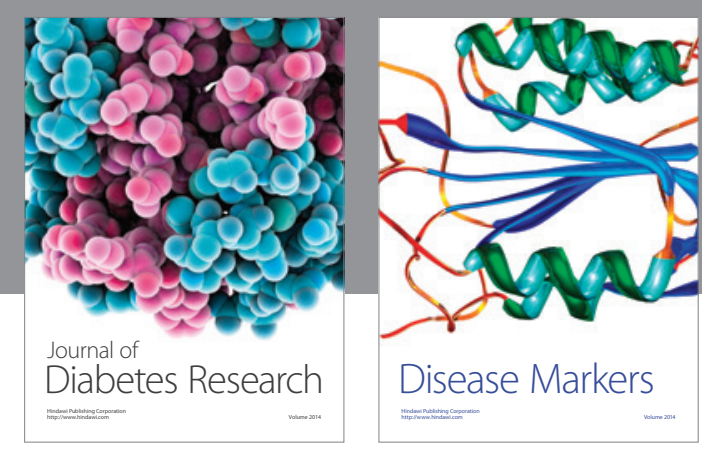

Disease Markers
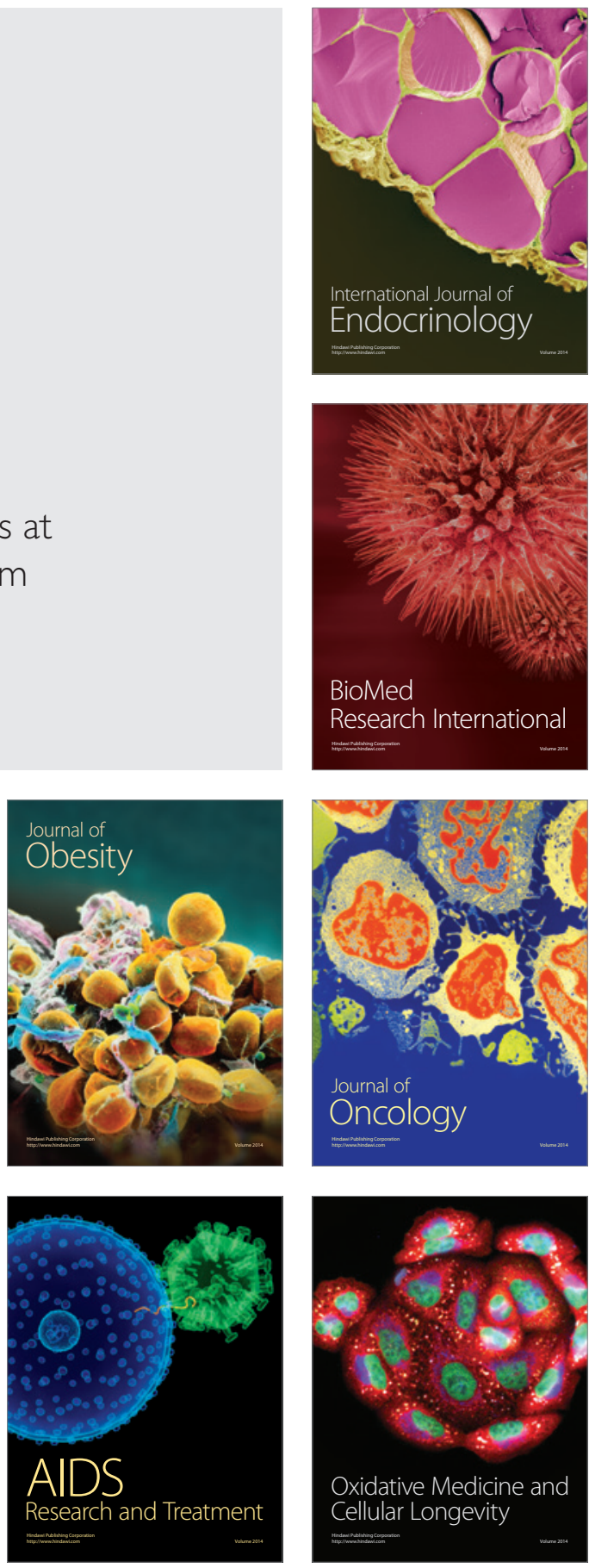